\title{
Screening of Conserved Non-Coding Elements with Enhanced Activity of SHOX Gene in PAR1 Region and Its Regulation Mechanism on SHOX Gene
}

\section{Huijiao Zhang}

Children's Hospital of Chongqing Medical University

\section{Xuejiao Xu}

Children's Hospital of Chongqing Medical University

\section{Shijie Xin}

Children's Hospital of Chongqing Medical University

Gaohui Zhu

Children's Hospital of Chongqing Medical University

Min Zhu ( $\triangle$ zhuminphd@163.com)

Children's Hospital of Chongqing Medical University https://orcid.org/0000-0001-8908-4332

\section{Research}

Keywords: SHOX Gene, conserved non-coding elements, CNEs, Regulation Mechanism

Posted Date: August 14th, 2020

DOl: https://doi.org/10.21203/rs.3.rs-54595/v1

License: (9) This work is licensed under a Creative Commons Attribution 4.0 International License. Read Full License 


\section{Abstract}

Background: Defects in conserved non-coding elements (CNEs) are associated with a large number of genetic diseases. The short-chain homeobox gene (SHOX) is regulated by different CNEs in the upstream and downstream, and these CNEs can act as enhancers as homeopathic regulatory elements. Abnormal CNEs upstream and downstream of the SHOX gene can result in short stature of different phenotypes.

Methods: This study screened all the CNEs with enhancer action in the PAR1 region of SHOX gene, of which CNE10 and CNE11 have not been reported internationally. We investigated the relationship between CNEs with enhancer action and different promoters of SHOX in HEK293T cells by dual luciferase reporter system. Among them, CNE-2 and CNE-3 up-regulated the activity of SHOX promoter 2, while CNE-5, CNE9, CNE10 and CNE11 up-regulated the activity of SHOX promoter 1.

Results: The six groups (CNE-5, CNE-3, CNE-2, CNE9, CNE10, CNE11) are considered to have an enhanced effect on the expression of the SHOX gene. CNE-2 and CNE-3 up-regulated the activity of SHOX promoter 2, while CNE-5, CNE9, CNE10 and CNE11 up-regulated the activity of SHOX promoter 1.

Conclusion: CNE-2 and CNE-3 and may have skipped SHOX promoter 1 to interact with SHOX promoter 2 through chromatin looping. The downstream CNE9, CNE10, and CNE11 may skip the interaction of SHOX promoter 2 with SHOX promoter 1, thereby regulating the expression of SHOX.

\section{Background}

With the deepening of the study of genomic non-coding regions, the researchers found that conserved non-coding elements (CNEs) regulate chromatin configuration, protein modification, RNA translation process and DNA transcription levels [1-5]. The occurrence of a large number of diseases is closely related to the abnormalities of CNEs, such as Rett syndrome [6], autism [7], short stature [8], pancreatic hypoplasia [9] and so on. In recent years, a large number of genes related to height have been found, such as NPPB, FGFR3, FLRT3, SOX9 and SHOX [10-14].

The short stature homeobox gene (SHOX) is located in the short-arm PAR1 region of human sex chromosomes and is a member of the homeobox gene transcription factor family [14]. It plays a crucial role in bone development and growth. Mutations in the SHOX gene affect bone growth in a dosedependent manner. Studies have found that in patients with a karyotype of 47, XXY with Kline syndrome and a karyotype of 47,XXX patients with triple X syndrome, the increase in SHOX dose is associated with a high body phenotype [15]. In addition, studies have found triploids in the PAR1 region containing the SHOX gene in tall women [16]. The reduction in SHOX dose is associated with short stature. A single dose deficiency of the SHOX gene affects approximately $2-3 \%$ of patients with Idiopathic Short Stature (ISS) and $70 \%$ of patients with Léri-Weill dyschondrosteosis (LWD). The homozygous deletion of the SHOX gene results in Langer mesomelic dysplasia (LMD) characterized by more severe short stature and skeletal malformations ${ }^{[17]}$. In addition to short stature, patients with SHOX gene deletions will show many skeletal malformations ranging from mild to severe, such as forearm shortening and flexion, Madelung 
malformation, short fourth metacarpal, elbow valgus and small mandible. However, some studies have found that the deletion of the SHOX gene regulatory region in the PRA1 region is identical to the phenotype caused by the deletion of the SHOX gene coding region [18].

Like most growth and development genes, the SHOX gene requires the regulation of spatio-temporal expression with the help of cis-regulatory elements such as enhancers [19]. Nitin Sabherwal et al [8] analyzed four LWD families and found that the SHOX gene coding region was intact, while the SHK downstream $200 \mathrm{~Kb}$ sequence fragment was deleted. It is speculated that the missing region of the patient contains some special components to regulate the expression of SHOX gene. This fragment was analyzed by comparative genomics to obtain 8 highly conserved non-coding sequences (CNEs). Studies have shown that three conserved non-coding sequences CNE4, CNE5, and CNE9 have enhanced activity in chicken embryonic limb development. Subsequently, the conserved non-coding sequences CNE-5, CNE3 , and CNE-2 upstream of SHOX were also confirmed to have enhanced activity, and sequence fragments containing CNEs upstream of the SHOX gene were confirmed to be deleted in short stature patients [2023]. The clinical phenotypes of CNEs deletion and SHOX coding region mutations in the SHOX gene are difficult to distinguish, so CNEs may act as cis-regulators to enhance the expression of SHOX gene.

It was found that CNEs with enhancer activity upstream and downstream of SHOX gene include CNE-2, CNE-3, CNE-5, CNE4, CNE5 and CNE9, of which CNE9 is the strongest enhancement sequence [8]. However, the existing research is basically located within $850 \mathrm{~kb}$ of the SHOX gene. In our previous study of 354 patients with ISS, we found that there is a deletion in the $1300 \mathrm{~kb}$ region downstream of the SHOX gene, but the clinical phenotype is relatively light, and it is estimated that the SHOX gene is $800 \mathrm{~kb}$ downstream. There are also CNEs that are present and cis-regulatory activity is present during limb development. At present, human genome CNEs are obtained by comparative genomics and bioinformatics methods, so this study will obtain and screen all CNEs (up to $1300 \mathrm{~kb}$ downstream) of SHOX genes by comparing genomics and bioinformatics.

At present, little is known about the regulation mechanism of SHOX gene by CNEs upstream and downstream of SHOX gene. Blaschke et al [24] found that the SHOX gene has two promoters, the second promoter is located in exon 2, and the two promoters produce different mRNAs encoding the same protein, with the same coding ability and different translational potency. . Clandia Durand et al [25] found that HOXA9 up-regulates the expression of SHOX gene in U2OS cells by binding to SHOX promoter 2 . According to the "core promoter" concept [24], different promoters compete for transcription factors and tissue-specific enhancer elements, and we speculate that these CNEs may exert potentiation by binding to different promoters of SHOX. Since SHOX has no orthologs in rodents, we chose to construct two pairs of SHOX genes with CNEs $(-2,-,-5,9,10,11)$ in vitro. In the luciferase reporter gene system, the relationship between each CNE and the SHOX gene promoter was investigated.

\section{Materials And Methods}

\section{Genomics analysis of CNEs for SHOX gene PRA1}


The ECR Browser and CONDOR databases were combined to determine the location of all CNEs of the SHOX gene PRA1, and the genomic sequence was searched using the UCSC genome browser (www.ucsc.edu/genome).

ECR Browser database screening CNEs (http://ecrBrowser.dcode), as was shown in Figure 1, we set 200 bp as the smallest sequence and select 70\% homology of zebrafish, pufferfish, Xenopus laevis, possum, chicken, dog, human.CONDOR database screening CNEs (http://condor.nimr.mrc.ac.uk) was shown in Table 1.

\section{Construction of green fluorescent protein particles containing different CNE}

As was shown in Table 2, each CNEs primer was designed, and each CNE was amplified by PCR to construct a pEGFP-N1 plasmid containing different CNE.

\section{Transfection of HEK293 cells with plasmids containing different CNE}

As was shown in Figure 2, the plasmid containing each CNEs was amplified and extracted, and transfected into HEK293T cell culture. HEK293T cells were cultured in DMEM medium containing 10\% fetal bovine serum (Gibco), added with double antibody, and cultured in a $37^{\circ} \mathrm{C}, 5 \% \mathrm{CO} 2$ incubator. The cells were passaged in 24-well plates $20 \mathrm{~h}$ to $24 \mathrm{~h}$ before transfection, and the cell density was about $0.7 \times 105$ cells $/ \mathrm{mL}$. Plasmid transfection was carried out according to the lipofectamine 2000 liposome transfection instructions. After $48 \mathrm{~h}$ of transfection, cells were harvested.

\section{Identification of different CNE enhancing activities by real-time fluorescent quantitative nucleic acid amplification detection system (Q-PCR)}

After the transfected cells were extracted with RNA, they were reverse transcribed into cDNA, and the enhanced activity of all CNEs was identified by Q-PCR. SHOX gene primer: upstream 5'-

GCATAAAGGCGTCATCTTGG-3', downstream 5'-GTTGGAAAGGCATCCGTAAG-3'.

\section{Localization of SHOX Promoter 2 Sequence}

The SHOX promoter 2 is located 432 bp upstream of the initiation codon AUG in the second exon of SHOX [24], and the position of the SHOX promoter 2 sequence on the X chromosome is determined by the UCSC genome browser (www.ucsc.edu/genome) as chrX511202 -511634.

\section{Construction of dual luciferase vectors}

As was shown in Figure 3, using psiCHECK-2 vector (Promega), CNE-2, CNE-3, and CNE-5 were located upstream of the SHOX promoter, and the two promoters of CNES and SHOX were spliced together by Overlap. The fragment was cloned into the upstream of the Luc gene using Bglll and Nhel. CNE9, CNE10 and CNE11 are located downstream of the SHOX promoter. The SHOX promoter was cloned upstream of the hRLuc gene with Bglll and Nhel, and the CNES gene was inserted into the Xhol and Notl sites. That is, the T7 promoter was replaced with the SHOX promoter. 
Each CNEs fragment was synthesized, and the design of each CNEs primer was as shown in Table 2. Each CNEs fragment and the control fragment were digested by PCR, and the enzyme was cut to complete the gel recovery. The competent cells were transformed, and the cells were picked up after transformation. The bacteria were shaken at $37^{\circ} \mathrm{C}$ for 250 hours at rpm for 14 hours, and the positive bacteria were sequenced by PCR.

\section{Dual luciferase assay}

The transfected cells were plated into 96-well plates and operated according to the instructions of the Dual-Luciferase Assay Kit (Promega).

\section{Statistical analysis method}

The count data in the study were described by frequency and percentage, and the measurement data were described by means of mean (standard deviation). The comparison between the two groups of samples was analyzed by chi-square analysis or t-test, and the comparison between the three groups and above was analyzed by differential analysis. Statistical analysis of data was performed using SPSS 23.0 software. Bilateral $\mathrm{P}<0.05$ was considered statistically significant.

\section{Results}

\section{Screening out CNES of SHOX gene PRA1}

We screened 18 conserved non-coding sequences using the comparative genomic approach. The positions of each CNE on the X chromosome are shown in Table 3 and Figure 4 (NCBI build 36.1). Q-PCR identified the expression of SHOX gene after transfection of cells containing different CNE plasmids, as shown in Table 5.

\section{Effect of each CNE on the expression of SHOX gene}

\section{Homogeneity test of variance}

The homogeneity test of SHOX gene expression was tested. The homogeneity test of variance showed that the SHOX gene expression was uneven between groups $(P=0.000,<0.05)$, and the sample size was small. Therefore, one-way ANOVA and nonparametric tests cannot be performed on SHOX gene expression. The use of t-test analysis method will increase the type I error. Therefore, the SHOX gene expression is changed to the SAS programming calculation using the Bootstrap method, and the sample rate is compared multiple times. The results are shown in Table 6 and Table 7.

From the above data, using the Bootstrap method for multi-sample pairwise comparison (Table 6), we can see that the untransfected group (no intervention on the cells, ie, not transferred into the plasmid) and the control group (adding an empty plasmid without CNEs) For comparison, $\mathrm{P}=0.96(>0.05)$, that is, $\mathrm{H} 1$ was rejected, and $\mathrm{HO}$ was accepted, and there was no statistical difference between the untransfected 
group and the control group. That is to say, the plasmid itself has no effect on the expression level of SHOX gene, that is, the influence of the plasmid on the cells is excluded, thereby affecting the change of the expression level of the SHOX gene.The P values of CNE-4, CNE2, CNE3, CNE4, CNE5, CNE6, CNE7, CNE8, CNE12, CNE13, CNE14, and CNE15 compared with the untransfected group were 0.706, 0.942, 1, 1, and 0.416 , respectively. $0.109,0.416,0.838,1,0.108,0.866$, and 0.932 are all greater than 0.05 . That is to say, there was no statistical difference between CNE-4, CNE2, CNE3, CNE4, CNE5, CNE6, CNE7, CNE8, CNE12, CNE13, CNE14, CNE15 and untransfected groups. That is, after the above CNEs interfere with the cells, there is no effect on the expression level of the SHOX gene.The P values of CNE-5, CNE-3, CNE-2, CNE9, CNE10, and CNE11 compared with the untransfected group were $<.0001,<.0001,<.0001,0.015$, 0.01 , and 0.007 , respectively, less than 0.05 . That is to say, there are statistical differences between the above six groups of CNE-5, CNE-3, CNE-2, CNE9, CNE10 and CNE11 and the untransfected group. Therefore, the above six groups (CNE-5, CNE-3, CNE-2, CNE9, CNE10, CNE11) are considered to have an enhanced effect on the expression of the SHOX gene.

\section{Relationship between CNES and SHOX promoter}

Control group and experimental group, two duplicate wells, three biological replicates. Using SPSS22. software, the mean and standard deviation of Rluc/Fluc in each CNE group are shown in Table 8. Compared with the control group, when SHOX Promoter1 was used, the values of Rluc/Fluc in CNE-2 and CNE-3 groups decreased, while the values of Rluc/Fluc in other groups increased in different magnitudes. When using SHOX Promoter2, the result is just the opposite. One-way analysis of variance was performed and the results of Tamhane's ST2 test are shown in Table 9. Thus, CNE-2 and CNE-3 up-regulated the activity of SHOX promoter 2, while CNE-5, CNE9, CNE10 and CNE11 up-regulated the activity of SHOX promoter 1 .

\section{Discussion}

Human height is determined by genetic factors and environmental factors, and is dominated by genetic factors. Short stature is one of the most common endocrine diseases in children. The abnormal incidence of SHOX gene in a large number of genes related to height is about $12.5 \%$ of all short stature patients, which is the focus of research on short stature and skeletal deformity.

SHOX gene defects or abnormalities in their CNEs can result in short stature of different phenotypes. The conserved non-coding sequences of the PAR1 region that have an enhancer effect on the SHOX gene have been reported in the international literature: CNE-2, CNE-3, CNE-5, CNE4, CNE5, CNE9. By expanding the screening region to $1300 \mathrm{~kb}$ downstream of the SHOX gene, we screened two new CNEs downstream of the SHOX gene, and verified that they also have enhanced activity.

Among all the conserved non-coding elements that have been reported, CNE9 is the most important regulatory element of the SHOX gene. Studies have confirmed that SHOX promoter 1 interacts with CNE9 through chromatin conformation capture technology, and CNE9 may enhance the expression of SHOX protein through chromatin loop formation [8]. The SHOX gene has two promoters, and the transcript 
5'UTR obtained by the promoter 2 is short and the translation efficiency is high. The transcript obtained by promoter 1 significantly inhibited translational efficiency due to the long $5^{\prime}$ UTR upstream of the major open reading frame [24]. Therefore, we speculate that each CNE may bind to a different promoter of SHOX, thereby exerting an enhancing effect. SHOX promoter 2 is a promoter within the gene. Currently, there is little research in the world. Claudia Durand [25] found that SHOX gene is a target gene of HOXA9, which can up-regulate the expression of SHOX gene in U2OS cells. The HOXA9 binding site was located in SHOX promoter 2 by immunoprecipitation and electrophoretic migration experiments, suggesting that HOXA9 may regulate SHOX gene expression through SHOX promoter 2.

In this study, plasmids containing SHOX different promoters and CNE were transfected into HEK293T cells. The relationship between CNEs and SHOX promoters was studied by dual luciferase assay. The results showed that CNE-2 and CNE-3 up-regulated the activity of SHOX promoter 2, while CNE-5, CNE9, CNE10 and CNE11 up-regulated the activity of SHOX promoter 1 . Therefore, we hypothesized that CNE-2 and CNE-3 mainly regulate the expression of SHOX gene through SHOX promoter 2, and CNE-5, CNE9, CNE10 and CNE11 regulate SHOX gene expression mainly through SHOX promoter 1 . The expression of SHOX gene is enhanced by the action of different promoters, which may be the mechanism by which non-coding sequences (CNEs) regulate the expression of SHOX genes.

The team of Guoliang $\mathrm{Li}^{[24]}$ identified the interaction between thousands of promoters and enhancers, including approximately 1000 ultra-long-range components (greater than $500 \mathrm{~Kb}$ ). The study observed that $\geq 40 \%$ of enhancers did not interact with their nearest promoter, but instead skipped their target promoter. The promoter 1 of SHOX is located between the upstream CNE-2, CNE-3 and SHOX promoter 2. We have introduced CNE-2 and CNE-3 and may have skipped SHOX promoter 1 to interact with SHOX promoter 2 through chromatin looping. The downstream CNE9, CNE10, and CNE11 may skip the interaction of SHOX promoter 2 with SHOX promoter 1, thereby regulating the expression of SHOX.

\section{Declarations}

\section{Ethics approval and consent to participate}

This article does not contain any studies with human participants or animals performed by any of the authors.

\section{Consent for publication:}

Not applicable.

\section{Availability of data and material:}

Not applicable.

\section{Funding}


This study was funded by the National Natural Science Foundation (81170723).

\section{Competing interests:}

There are no potential conflicts of interest to disclose.

\section{Acknowledgements:}

Not applicable.

\section{References}

1. Narlikar L, Ovcharenko I. Identifying regulatory elements in eukaryotic genomes. Brief Funct Genomic Proteomic 2009;8(4):215-30.

2. Woolfe A, Goodson M, Goode DK, Snell P, McEwen GK, Vavouri T, Smith SF, North P, Callaway H, Kelly K, Walter K, Abnizova I, Gilks W, Edwards YJ, Cooke JE, Elgar G. Highly conserved non-coding sequences are associated with vertebrate development. PLoS Biol 2005;3(1):e7.

3. Visel A, Bristow J, Pennacchio LA. Enhancer identification through comparative genomics. Semin Cell Dev Biol 2007;18(1):140-52.

4. Pennacchio LA, Ahituv N, Moses AM, Prabhakar S, Nobrega MA, Shoukry M, Minovitsky S, Dubchak I, Holt A, Lewis KD, Plajzer-Frick I, Akiyama J, De Val S, Afzal V, Black BL, Couronne O, Eisen MB, Visel $A$, Rubin EM. In vivo enhancer analysis of human conserved non-coding sequences. Nature 2006;444(7118):499-502.

5. Ahituv N, Zhu Y, Visel A, Holt A, Afzal V, Pennacchio LA, Rubin EM. Deletion of ultraconserved elements yields viable mice. PLoS Biol 2007;5(9):e234.

6. Liu J, Francke U. Identification of cis-regulatory elements for MECP2 expression. Hum Mol Genet 2006;15(11):1769-82.

7. Richler E, Reichert JG, Buxbaum JD, Mclnnes LA. Autism and ultraconserved non-coding sequence on chromosome 7q. Psychiatr Genet 2006;16(1):19-23.

8. Sabherwal N, Bangs F, Röth R, Weiss B, Jantz K, Tiecke E, Hinkel GK, Spaich C, Hauffa BP, van der Kamp H, Kapeller J, Tickle C, Rappold G. Long-range conserved non-coding SHOX sequences regulate expression in developing chicken limb and are associated with short stature phenotypes in human patients. Hum Mol Genet 2007;16(2):210-22.

9. Weedon MN, Cebola I, Patch AM, Flanagan SE, De Franco E, Caswell R, Rodríguez-Seguí SA, ShawSmith C, Cho CH, Allen HL, Houghton JA, Roth CL, Chen R, Hussain K, Marsh P, Vallier L, Murray A; International Pancreatic Agenesis Consortium, Ellard S, Ferrer J, Hattersley AT. Recessive mutations in a distal PTF1A enhancer cause isolated pancreatic agenesis. Nat Genet 2014;46(1):61-64.

10. Aza-Carmona M, Barca-Tierno V, Hisado-Oliva A, Belinchón A, Gorbenko-del Blanco D, Rodriguez Jl, Benito-Sanz S, Campos-Barros A, Heath K NPPB and ACAN, two novel SHOX2 transcription targets implicated in skeletal development. PLoS One 2014;9(1):e83104. 
11. Decker E, Durand C, Bender S, Rödelsperger C, Glaser A, Hecht J, Schneider KU, Rappold G. FGFR3 is a target of the homeobox transcription factor SHOX in limb development. Hum Mol Genet 2011;20(8):1524-35.

12. Marchini A, Häcker B, Marttila T, Hesse V, Emons J, Weiss B, Karperien M, Rappold G. BNP is a transcriptional target of the short stature homeobox gene SHOX. Hum Mol Genet 2007;16(24):30817.

13. Wagner T, Wirth J, Meyer J, Zabel B, Held M, Zimmer J, Pasantes J, Bricarelli FD, Keutel J, Hustert E, Wolf U, Tommerup N, Schempp W, Scherer G. Autosomal sex reversal and campomelic dysplasia are caused by mutations in and around the SRY-related gene SOX9. Cell 1994;79(6):1111-20.

14. Rao E, Weiss B, Fukami M, Rump A, Niesler B, Mertz A, Muroya K, Binder G, Kirsch S, Winkelmann M, Nordsiek G, Heinrich U, Breuning MH, Ranke MB, Rosenthal A, Ogata T, Rappold GA.

Pseudoautosomal deletions encompassing a novel homeobox gene cause growth failure in idiopathic short stature and Turner syndrome. Nat Genet 1997;16(1):54-63.

15. Ogata T, Matsuo N, Nishimura G. SHOX haploinsufficiency and overdosage: impact of gonadal function status. J Med Genet 2001;38(1):1-6.

16. Ogata T, Inokuchi M, Ogawa M. Growth pattern and body proportion in a female with short stature homeobox-containing gene overdosage and gonadal estrogen deficiency. Eur J Endocrinol 2002;147(2):249-54.

17. Zinn AR, Wei F, Zhang L, Elder FF, Scott Cl Jr, Marttila P, Ross JL. Complete SHOX deficiency causes Langer mesomelic dysplasia. Am J Med Genet 2002;110(2):158-63.

18. Rappold G, Blum WF, Shavrikova EP, Crowe BJ, Roeth R, Quigley CA, Ross JL, Niesler B. Genotypes and phenotypes in children with short stature: clinical indicators of SHOX haploinsufficiency. J Med Genet 2007;44(5):306-13.

19. Kleinjan DA, van Heyningen V. Long-range control of gene expression: emerging mechanisms and disruption in disease. Am J Hum Genet 2005;76(1):8-32.

20. Durand C, Bangs F, Signolet J, Decker E, Tickle C, Rappold G. Enhancer elements upstream of the SHOX gene are active in the developing limb. Eur J Hum Genet 2010;18(5):527-32.

21. Benito-Sanz S, Aza-Carmona M, Rodríguez-Estevez A, Rica-Etxebarria I, Gracia R, Campos-Barros A, Heath KE. Identification of the first PAR1 deletion encompassing upstream SHOX enhancers in a family with idiopathic short stature. Eur J Hum Genet 2012;20(1):125-7.

22. Kenyon EJ, McEwen GK, Callaway H, Elgar G. Functional analysis of conserved non-coding regions around the short stature hox gene (shox) in whole zebrafish embryos. PLoS One 2011;6(6):e21498.

23. Chen J, Wildhardt G, Zhong Z, Röth R, Weiss B, Steinberger D, Decker J, Blum WF, Rappold G.

Enhancer deletions of the SHOX gene as a frequent cause of short stature: the essential role of a 250 kb downstream regulatory domain. J Med Genet 2009;46(12):834-9.

24. Blaschke RJ, Töpfer C, Marchini A, Steinbeisser H, Janssen JW, Rappold GA. Transcriptional and translational regulation of the Leri-Weill and Turner syndrome homeobox gene SHOX. J Biol Chem 2003;278(48):47820-6. 
25. Durand C, Decker E, Roeth R, Schneider KU, Rappold G. The homeobox transcription factor HOXA9 is a regulator of SHOX in U2OS cells and chicken micromass cultures. PLoS One 2012;7(9):e45369.

\section{Tables}

Table 1.

CONDOR database screening CNEs.

\begin{tabular}{|llllll|}
\hline CNE ID & FEATURE & START (TSS) & END (TSS) & LENGTH & $\%$ ID \\
\hline CRCNE00011081 & CNE & -195701 & -195494 & 208 & 72.1 \\
\hline CRCNE00011074 & CNE & -193149 & -193028 & 122 & 70 \\
\hline CRCNE00011082 & CNE & -192987 & -192825 & 163 & 77.5 \\
\hline CRCNE00011083 & CNE & -169972 & -169884 & 89 & 71.1 \\
\hline CRCNE00011085 & CNE & -158127 & -158008 & 120 & 73.8 \\
\hline CRCNE00011086 & CNE & -136633 & -136549 & 85 & 77.3 \\
\hline CRCNE00011089 & CNE & -74966 & -74667 & 300 & 72.6 \\
\hline CRCNE00011091 & CNE & 7031 & 7288 & 258 & 76.3 \\
\hline CRCNE00011094 & UTR & 20617 & 20700 & 84 & 70.9 \\
\hline CRCNE00011096 & CNE & 159389 & 159448 & 60 & 82.1 \\
\hline CRCNE00011097 & CNE & 159552 & 159838 & 287 & 75.8 \\
\hline CRCNE00011098 & CNE & 159888 & 160052 & 165 & 77.2 \\
\hline CRCNE00011100 & CNE & 174476 & 174564 & 89 & 78.8 \\
\hline CRCNE00011101 & CNE & 189151 & 189322 & 172 & 74.5 \\
\hline CRCNE00011104 & CNE & 243529 & 243706 & 178 & 72.3 \\
\hline CRCNE00011107 & CNE & 342371 & 342406 & 36 & 71.5 \\
\hline CRCNE00011108 & CNE & 342549 & 342669 & 121 & 72.4 \\
\hline CRCNE00011109 & CNE & 372171 & 372230 & 60 & 70.1 \\
\hline CRCNE00011110 & CNE & 404123 & 404334 & 212 & 81.1 \\
\hline CRCNE00011111 & CNE & 603319 & 603360 & 42 & 78.2 \\
\hline CRCNE00011114 & CNE & 619900 & 620143 & 244 & 80 \\
\hline
\end{tabular}


Table 2.

Sequences of all the primers.

\begin{tabular}{|c|c|c|}
\hline & Upstream primer & Downstream primer \\
\hline CNE-5 & $\begin{array}{l}\text { 5'- } \\
\text { CGCGGATCCCAAACACGGAACAGCACACT- } \\
3^{\prime}\end{array}$ & $\begin{array}{l}\text { 5'-GGCGAATTCTCTCCGCCTCTTCGGCAGA- } \\
3^{\prime}\end{array}$ \\
\hline CNE-4 & $\begin{array}{l}\text { 5'- } \\
\text { GCGAGATCTTAGATAAGGGACCTCCTCTG- } \\
3^{\prime}\end{array}$ & $\begin{array}{l}\text { 5'- } \\
\text { CGCGGAATTCGATTTTCTGGCTGGAAATGG- } \\
3^{\prime}\end{array}$ \\
\hline CNE-3 & $\begin{array}{l}\text { 5'- } \\
\text { GCCAGATCTCGAGGTGGATCAAAGTGTCA- } \\
3^{\prime}\end{array}$ & $\begin{array}{l}\text { 5'- } \\
\text { GGCGAATTCTGCTCTGCCATATCCTCAATC- } \\
3^{\prime}\end{array}$ \\
\hline CNE-2 & $\begin{array}{l}\text { 5'- } \\
\text { AATAGATCTACATGACAGCCGGGCCTCTG- } \\
3^{\prime}\end{array}$ & $\begin{array}{l}\text { 5'-AGCGAATTCGCGAGCCATAAAACAAGCTG- } \\
3^{\prime}\end{array}$ \\
\hline CNE2 & 5'-CCGCGGCGACTAATGATATTCCGCAA-3' & 5'-TCTAGATTACCACATTCTCCAAGGAC-3' \\
\hline CNE3 & 5'-CCGCGGCTCTTCTCCTGACCTCCTAA-3' & 5'-TCTAGACTCTCTAATAGATCTAATTA-3' \\
\hline CNE4 & 5'-CCGCGGTTTGCAGTGTTATGCACTCG-3' & 5'-TCTAGACTGGTGTTCGGTCTCAGCTC-3' \\
\hline CNE5 & 5'-CCGCGGGCCTCCCTCGGGAGCGATTG-3' & 5'-TCTAGACATCCTCATCCTGCCTTCGA-3' \\
\hline CNE6 & 5'-CCGCGGGTGCAGGGAAGCTCCTTCTG-3' & 5'-TCTAGATACCCTAAGCCCTTCCTTCC-3' \\
\hline CNE7 & 5'-CCGCGGGAGGCTGCAGCTCACCCCGC-3' & 5'-TCTAGAAAACTGCACAGACCAGGTCT-3' \\
\hline CNE8 & 5'-CCGCGGTCCCCTCTGAGCCTGGCAGG-3' & 5'-TCTAGACTCCATATCCCTGCAGAGAC-3' \\
\hline CNE9 & 5'-CCGCGGTATACTTTACTTCTTTGCTG-3' & 5'-TCTAGATTGTGTCTGCAGTGTCCCCT-3' \\
\hline CNE10 & $\begin{array}{l}\text { 5'-ATTAATAGGAAACACCTGTGCTGAAGAC- } \\
3^{\prime}\end{array}$ & $\begin{array}{l}\text { 5'-AAGCTTTTGTGTTCTGATTAGCAACCGC- } \\
3^{\prime}\end{array}$ \\
\hline CNE11 & 5'-ATTAATACATCTGTTCCCATTTTCTCCT-3' & 5'-AAGCTTGGGGGTGAGATTCCACCGT -3' \\
\hline CNE12 & 5'-ATTAATAGGGGAGGCGTCGGGGA -3' & 5'-AAGCTTCTCTAGATCTGGGGACTC-3' \\
\hline CNE13 & 5'-CATATGCATTTTCTССССТСТСТT-3' & 5'-AAGCTTCACGTCTATTTAGTCAGC -3' \\
\hline CNE14 & 5'-ATTAATGCAAGCAGCCCCCACGCC -3' & 5'-AAGCTTGAGGCTGGGCGGGGCTGA -3' \\
\hline CNE15 & $\begin{array}{l}\text { 5'-CATATGTTTGAATGAATGCATGCGTGCT- } \\
3^{\prime}\end{array}$ & 5'-AAGCTTTTTGTCATTGCAGGACTT-3' \\
\hline
\end{tabular}


Table 3.

primer sequences.

\begin{tabular}{|ll|}
\hline Primer name & Primer sequence \\
\hline CNE-2-Bglll/Nhel-F & tcacatggctcgacagatctACATGACAGCCGGGCCTCTG \\
\hline CNE-2-R & AAAAGCAAACTCCAGTTTTCGCGAGCCATAAAACAAGCTG \\
\hline CNE-3-Bglll/Nhel-F & tcacatggctcgacagatctCGAGGTGGATCAAAGTGTCA \\
\hline CNE-3-R & AAAGCAAACTCCAGTTTTCTGCTCTGCCATATCCTCAAT \\
\hline CNE-5-Bglll/Nhel-F & tcacatggctcgacagatctCAAACACGGAACAGCACACT \\
\hline CNE-5-R & AAAAGCAAACTCCAGTTTTCTCTCCGCCTCTTCGGCAGA \\
\hline CNE9-Xhol/Notl-F & ATTCTAGGCGATCGCTCGAGTATACTTTACTTCTTTGCTG \\
\hline CNE9-Xhol/Notl-R & TTTTATTGCGGCCAGCGGCCGCTTGTGTCTGCAGTGTCCCCT \\
\hline CNE10-Xhol/Notl-F & ATTCTAGGCGATCGCTCGAGAGGAAACACCTGTGCTGAAGAC \\
\hline CNE10-Xhol/Notl-R & TTTTATTGCGGCCAGCGGCCGCTTGTGTTCTGATTAGCAACCGC \\
\hline CNE11-Xhol/Notl-F & ATTCTAGGCGATCGCTCGAGACATCTGTTCCCATTTTCTCCT \\
\hline CNE11-Xhol/Notl-R & TTTTATTGCGGCCAGCGGCCGCGGGGGTGAGATTCCACCGT \\
\hline
\end{tabular}

Table 4.

Positions of CNEs on the $\mathrm{X}$ chromosome.

\begin{tabular}{|llll|}
\hline CNE-5 & $318348-318915$ & CNE-4 & $353479-353678$ \\
\hline CNE-3 & $380270-380673$ & CNE-2 & $436601-437238$ \\
\hline CNE 2 & $638305-638742$ & CNE 3 & $664440-665063$ \\
\hline CNE 4 & $684085-684740$ & CNE 5 & $720825-721850$ \\
\hline CNE 6 & $735900-736360$ & CNE 7 & $750700-751220$ \\
\hline CNE 8 & $731550-732300$ & CNE 9 & $804746-805567$ \\
\hline CNE10 & $853825-854598$ & CNE11 & $883653-883894$ \\
\hline CNE12 & $915747-916019$ & CNE13 & $1114843-1115300$ \\
\hline CNE14 & $1119420-1119721$ & CNE15 & $1131168-1131851$ \\
\hline
\end{tabular}


Table 5.

SHOX gene expression.

\begin{tabular}{|llll|}
\hline Different CNES & Sample 1 & Sample 2 & Sample 3 \\
\hline CNE-5 & 1.91365 & 2.44823 & 2.10116 \\
\hline CNE-4 & 0.7653 & 0.91582 & 0.84084 \\
\hline CNE-3 & 2.22684 & 2.45993 & 2.45307 \\
\hline CNE-2 & 2.29332 & 2.51497 & 2.55608 \\
\hline CNE2 & 0.84323 & 0.89234 & 0.90744 \\
\hline CNE3 & 0.87803 & 0.94315 & 0.96864 \\
\hline CNE4 & 0.97463 & 0.9769 & 1.21051 \\
\hline CNE5 & 0.77271 & 0.77522 & 0.85996 \\
\hline CNE6 & 0.68887 & 0.80059 & 0.68429 \\
\hline CNE7 & 0.75343 & 0.85214 & 0.80208 \\
\hline CNE8 & 0.80843 & 0.82453 & 0.95055 \\
\hline CNE9 & 2.6425 & 3.08682 & 2.72186 \\
\hline CNE10 & 3.49023 & 3.44778 & 3.73476 \\
\hline CNE11 & 4.1259 & 4.3309 & 3.93727 \\
\hline CNE12 & 0.99331 & 0.91454 & 1.07585 \\
\hline CNE13 & 0.70353 & 0.66955 & 0.79872 \\
\hline CNE14 & 0.79427 & 0.93306 & 0.87055 \\
\hline CNE15 & 0.85231 & 0.93256 & 0.8534 \\
\hline Untransfected group & 1.00000 & 1.00000 & 1.00000 \\
\hline Control group & 0.87323 & 0.83202 & 0.94974 \\
\hline
\end{tabular}


Table 6.

The mean and standard deviation of the CNEs.

\begin{tabular}{|lllll|}
\hline Variable & group & NumObs & Mean & Standard Deviation \\
\hline $\mathrm{x}$ & CNE-2 & 3 & 2.4548 & 0.1413 \\
\hline $\mathrm{x}$ & CNE-3 & 3 & 2.3799 & 0.1326 \\
\hline $\mathrm{x}$ & CNE-4 & 3 & 0.8407 & 0.0753 \\
\hline $\mathrm{x}$ & CNE-5 & 3 & 2.1543 & 0.2712 \\
\hline $\mathrm{x}$ & CNE10 & 3 & 3.5576 & 0.1549 \\
\hline $\mathrm{x}$ & CNE11 & 3 & 4.1314 & 0.1969 \\
\hline $\mathrm{x}$ & CNE12 & 3 & 0.9946 & 0.0807 \\
\hline $\mathrm{x}$ & CNE13 & 3 & 0.7239 & 0.067 \\
\hline $\mathrm{x}$ & CNE15 & 3 & 0.866 & 0.0695 \\
\hline $\mathrm{x}$ & CNE2 & 3 & 0.8794 & 0.046 \\
\hline $\mathrm{x}$ & CNE3 & 3 & 0.881 & 0.0336 \\
\hline $\mathrm{x}$ & CNE4 & 3 & 0.9299 & 0.0467 \\
\hline $\mathrm{x}$ & CNE5 & 3 & 1.054 & 0.1355 \\
\hline $\mathrm{x}$ & CNE6 & 3 & 0.8026 & 0.0497 \\
\hline $\mathrm{x}$ & CNE7 & 3 & 0.7246 & 0.0659 \\
\hline $\mathrm{x}$ & CNE8 & 3 & 0.8026 & 0.0494 \\
\hline $\mathrm{x}$ & CNE9 & 3 & 0.8612 & 0.0778 \\
\hline $\mathrm{x}$ & Control group & 2.8171 & 0.237 \\
\hline $\mathrm{x}$ & Untransfected group & 3 & 1 & 0 \\
\hline
\end{tabular}


Table 7.

Results of Bootstrap method of SHOX gene expession.

\begin{tabular}{|llll|}
\hline Variable & Contrast & Raw & Bootstra $p$ \\
\hline $\mathrm{x}$ & Untransfected group-CNE-2 & $<.0001$ & $<.0001$ \\
\hline $\mathrm{x}$ & Untransfected group-CNE-3 & $<.0001$ & $<.0001$ \\
\hline $\mathrm{x}$ & Untransfected group-CNE-4 & 0.1155 & 0.706 \\
\hline $\mathrm{x}$ & Untransfected group-CNE-5 & $<.0001$ & $<.0001$ \\
\hline $\mathrm{x}$ & Untransfected group-CNE10 & $<.0001$ & $<.0001$ \\
\hline $\mathrm{x}$ & Untransfected group-CNE11 & $<.0001$ & $<.0001$ \\
\hline $\mathrm{x}$ & Untransfected group-CNE12 & 0.9565 & 1 \\
\hline $\mathrm{x}$ & Untransfected group-CNE13 & 0.0081 & 0.108 \\
\hline $\mathrm{x}$ & Untransfected group-CNE14 & 0.1835 & 0.866 \\
\hline $\mathrm{x}$ & Untransfected group-CNE15 & 0.2305 & 0.932 \\
\hline $\mathrm{x}$ & Untransfected group-CNE2 & 0.2366 & 0.942 \\
\hline $\mathrm{x}$ & Untransfected group-CNE3 & 0.4834 & 1 \\
\hline $\mathrm{x}$ & Untransfected group-CNE4 & 0.5885 & 1 \\
\hline $\mathrm{x}$ & Untransfected group-CNE5 & 0.0531 & 0.416 \\
\hline $\mathrm{x}$ & Untransfected group-CNE6 & 0.0082 & 0.109 \\
\hline $\mathrm{x}$ & Untransfected group-CNE7 & 0.053 & 0.416 \\
\hline $\mathrm{x}$ & Untransfected group-CNE8 & 0.1686 & 0.838 \\
\hline $\mathrm{x}$ & Untransfected group-CNE9 & $<.0001$ & $<.0001$ \\
\hline
\end{tabular}


Table 8.

The mean and standard deviationof the CNE Rluc/Fluc with alternative promoters.

\begin{tabular}{|llllll|}
\hline \multirow{2}{*}{ Group } & \multicolumn{2}{l}{ SHOX Promoter1 } & \multicolumn{2}{l|}{ SHOX Promoter2 } \\
\cline { 2 - 6 } & Mean & Standard Deviation & $n^{*}$ & Mean & Standard Deviation \\
\hline CNE-2 & 0.001387387 & 0.00021524 & 6 & 0.4671146968 & 0.0473773188 \\
\hline CNE-3 & 0.00098635 & 0.000125069 & 6 & 0.3372994294 & 0.0443654808 \\
\hline CNE-5 & 0.00252202 & 0.000348054 & 6 & 0.1748092513 & 0.0067065181 \\
\hline CNE9 & 0.004070261 & 0.000821294 & 6 & 0.0103124670 & 0.0013631790 \\
\hline CNE10 & 0.003170489 & 0.000670258 & 6 & 0.0229730133 & 0.0004915452 \\
\hline CNE11 & 0.003179026 & 0.000625019 & 6 & 0.0396210146 & 0.004682929255 \\
\hline Control & 0.001865138 & 0.000322009 & 6 & 0.2071832302 & 0.0235008942 \\
\hline
\end{tabular}

*sample size.

Table 9.

The $\mathrm{P}$ value of the CNE Rluc/Fluc with alternative promoters.

\begin{tabular}{|lll|}
\hline Group & SHOX Promoter1 & SHOX Promoter2 \\
\hline CNE-2 & 0.022 & 0.000 \\
CNE-3 & 0.001 & 0.006 \\
\hline CNE-5 & 0.023 & 0.323 \\
CNE9 & 0.000 & 0.000 \\
CNE10 & 0.004 & 0.000 \\
\hline CNE11 & 0.004 & 0.000 \\
\hline
\end{tabular}

Figures 


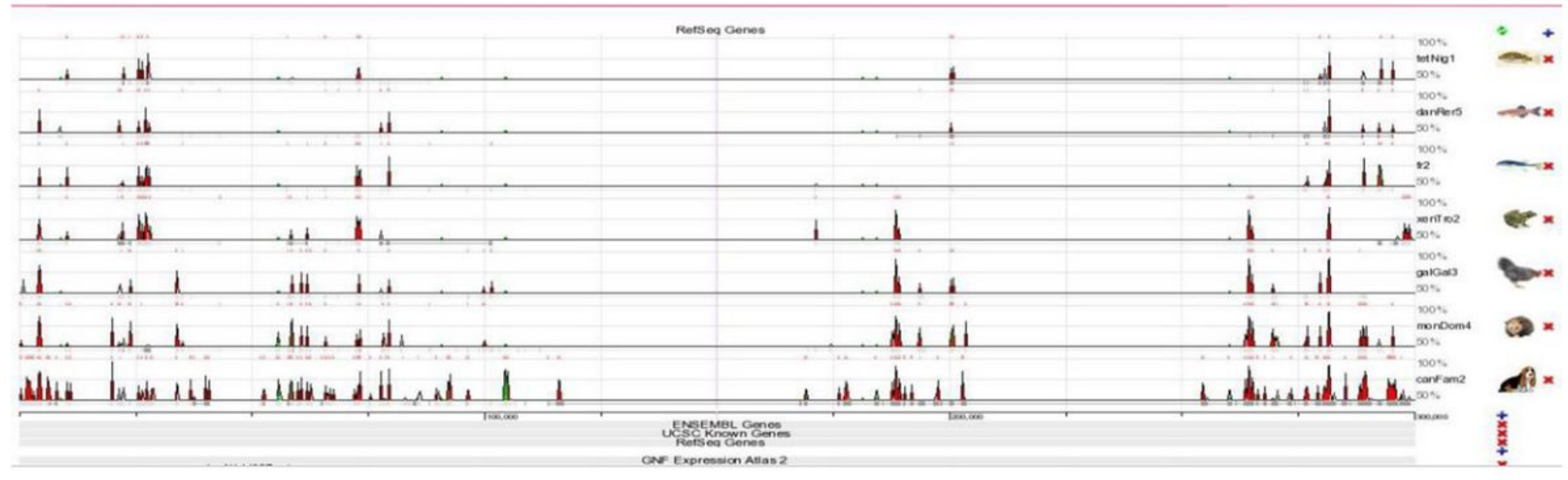

Figure 1

Diagram of comparative genomic analysis. 


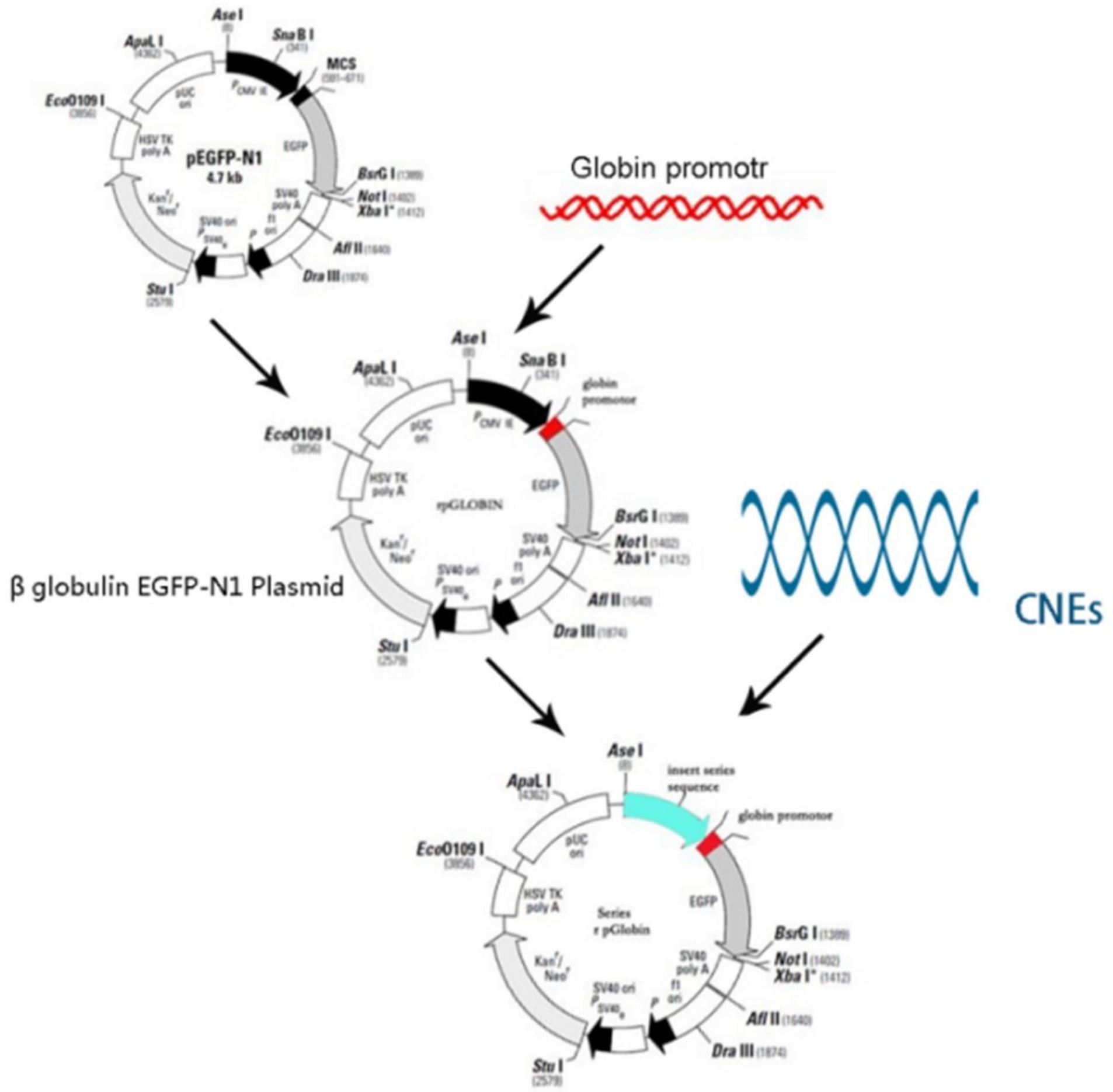

Final plasmid which containing different CNES

Figure 2

Diagram of plasmids construction. 


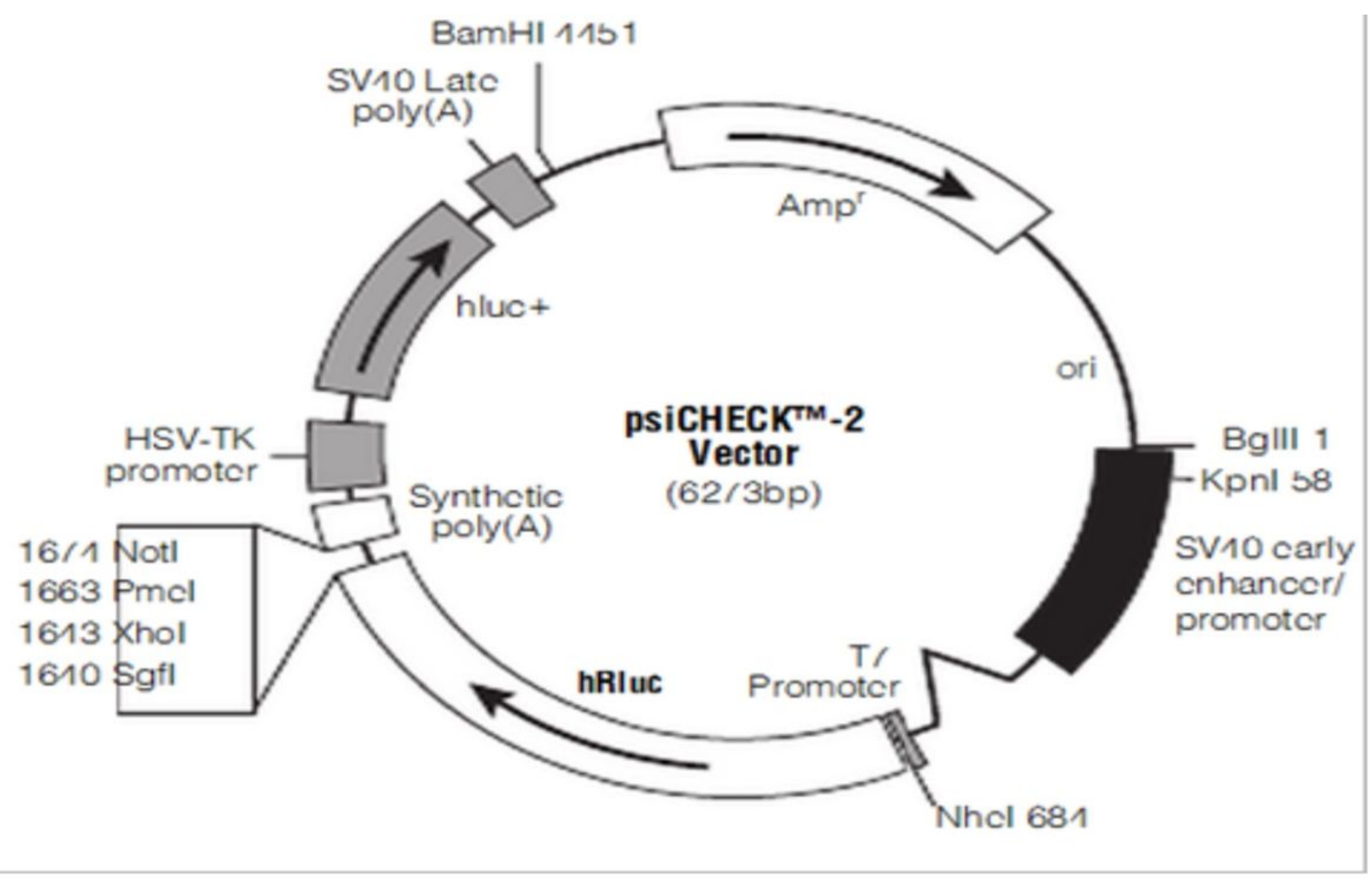

Figure 3

The schematic diagram of PsiCHECK-2 vector.

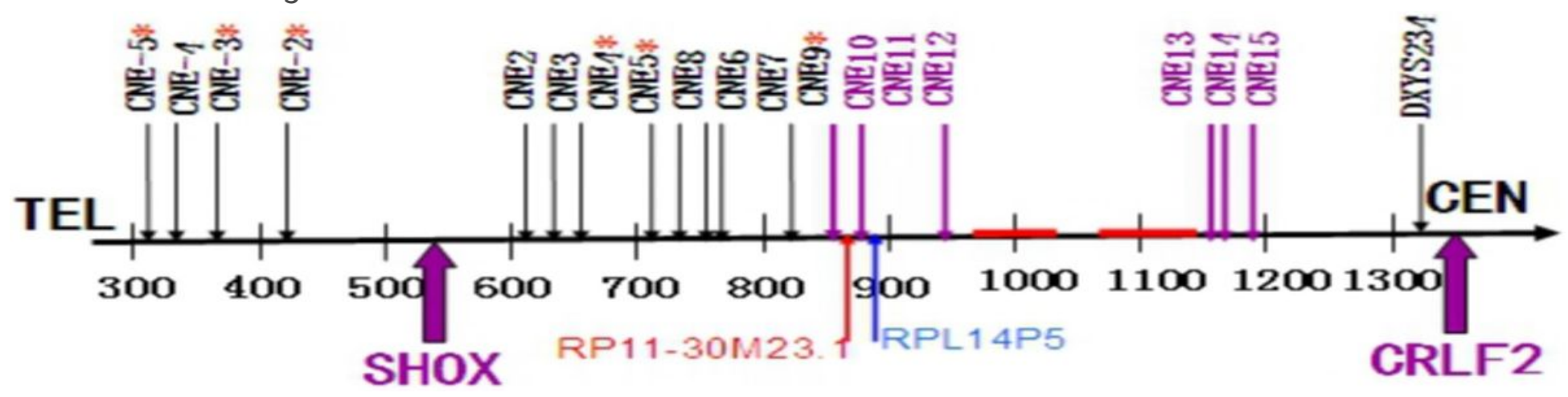

Figure 4

Diagram of the CNEs positions on the X chromosome. TEL:Telomere SHOX: Short homeobox gene RP1130M23.1: RNA gene :Sequence dead zone: CNEs with enhanced activity during chicken limb development CEN: Silk point CRLF2:Cytokine similar receptor 2 gene RPL14P5:Pseudogene CNE: Conserved non-coding sequence 